\title{
The Oxyopidae (lynx spiders) of New Zealand
}

\author{
COR J. VINK \\ Ecology \& Entomology Group; Soil, Plant and Ecological Sciences \\ Division; PO Box 84, Lincoln University; New Zealand \\ vinkc@lincoln.ac.nz
}

\author{
PhIL J. SiRvid \\ Museum of New Zealand Te Papa Tongarewa \\ PO Box 467, Wellington, New Zealand \\ phils@tepapa.govt.nz
}

\begin{abstract}
The spider family Oxyopidae is revised for New Zealand. The sole species, Oxyopes gracilipes (White, 1849), occurring nationwide, is redescribed and distribution records are given. It is hypothesised that $O$. gracilipes is Australian in origin.
\end{abstract}

Keywords: Oxyopidae, Oxyopes, revision, New Zealand, Australia, new synonymy

\section{INTRODUCTION}

Oxyopidae (lynx spiders) have a worldwide distribution and are most speciose in tropical and subtropical regions (Brady, 1964). This family consists of nine genera containing 410 species (N.I. Platnick, pers.comm.) and is considered to be part of the super-family Lycosoidea (Griswold, 1993). The largest genus, Oxyopes, contains over 270 species. (N.I. Platrick, pers. comm.) and has a worldwide distribution (Dondale \& Redner, 1990). The diagnostic family characters are a unique hexagonal eye arrangement, very tapered abdomen and heavy spination on the legs (Dondale \& Redner, 1990).

Oxyopids are not web builders. Rather, they are diurnal cursorial hunters and are most commonly found amongst the stems of tall grasses and low shrubs (Comstock, 1912; Brady, 1964; Brady, 1975; Dondale \& Redner, 1990). The eggs are laid in tough silken sacs, which are anchored to leaves and twigs (Whitcomb, 1962; Cutler et al., 1977). Lynx spiders are important predators of many serious arthropod pests throughout the world. Studies of agroecosystems in Japan (Kayashima, 1961; Nakasuji et al., 1973), India (Singh et al., 1975; Sharma \& Sarup, 1979) and North America (Young \& Lockley, 1985; Agnew \& Smith, 1989) have shown lynx spiders to be numerically dominant and significant predators.

Despite being common throughout New Zealand, oxyopids have attracted little attention. White (1849) published a poor description of Sphasus gracilipes from material collected in 1841 during the expedition of H.M.S. Erebus and Terror (Forster, 1967). In 1884, Urquhart described Sphasus gregarius from Karaka, south of Auckland. His description is detailed and includes illustrations. With the exception of some catalogues, all subsequent references to New Zealand oxyopids have been to Oxyopes gregarius (Urquhart, 1884) - Oxyopes Latreille is the senior synonym of Sphasus Walckenaer (Brady, 1964). Oxyopes gregarius was listed by Berland (1932) as part of the New Caledonian fauna. Parrott (1946) stated that there is one species, $O$. gregarius, which is common throughout New Zealand and "is somewhat variable in colour and size". Forster and Forster (1973) suggested the presence of "other undescribed species" of this family in New Zealand. 
We have examined oxyopid material from all over New Zealand (including offshore islands) and relevant Australian specimens, and have concluded that there is only the one species, Oxyopes gracilipes (White, 1849), present in New Zealand. In this paper we give a redescription and a full synonymy. Specimens examined for this revision are deposited in the following institutions: NZAC, Landcare Research, Auckland; Auckland Museum, Auckland; Museum of New Zealand Te Papa Tongarewa, Wellington; Entomology Research Museum, Lincoln University, Canterbury; Otago Museum, Dunedin. The twoletter regional codes used in locality data are those of Crosby et al. (1998).

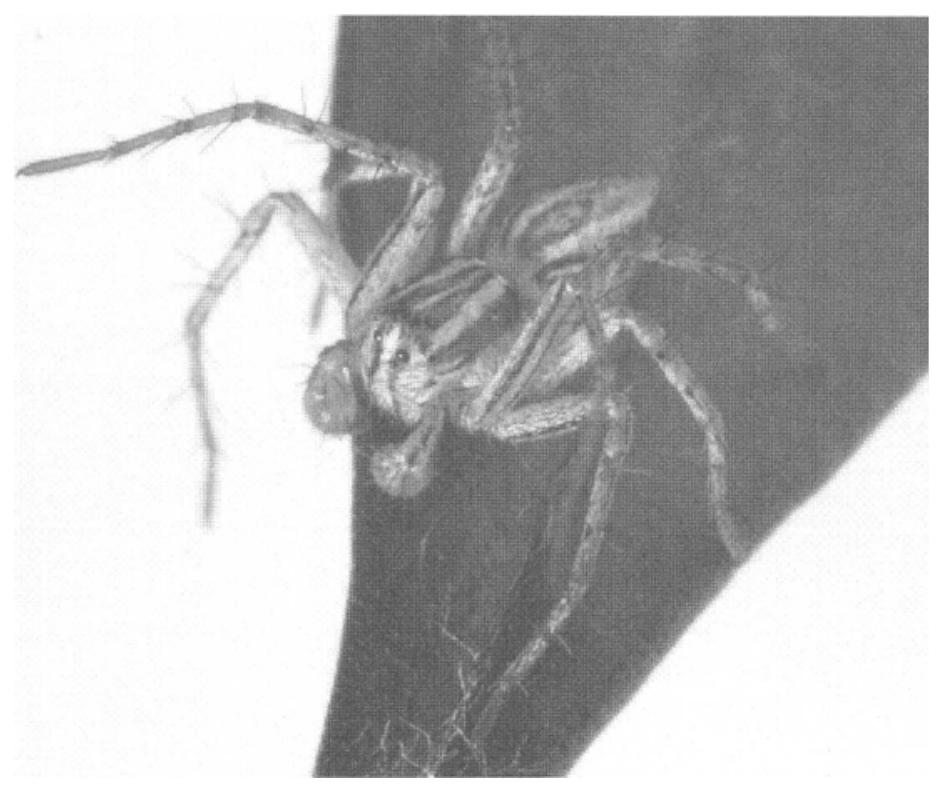

Fig. 1: Oxyopes gracilipes, subadult male

\section{SYSTEMATICS}

Oxyopes gracilipes (White, 1849)

$$
\text { Figures } 1 \text { - } 8
$$

Sphasus gracilipes White, 1849: 5

Sphasus gracilipes; White, 1850: 52. Identical to White, 1849

Sphasus gregarius Urquhart, 1884: 51, pl. xi, Figs 20a-e. New synonymy

Oxyopes gregarius (Urquhart); Urquhart, 1885: 201.

Oxyopes gregarius (Urquhart); Urquhart, 1891: 229. Listed only

Spharus [sic] gracilipes White; Urquhart, 1896: 284. Listed only

Oxyopes gregarius (Urquhart); Hutton, 1904: 244. Listed only

Oxyopes gracilipes (White); Hutton, 1904: 244. Listed only

Oxyopes gregarius (Urquhart); Dalmas, 1917: 415

Oxyopes gregarius (Urquhart); Berland, 1932: 296

Oxyopes gregarius (Urquhart); Parrott, 1946: 67

Oxyopes gracilipes (White); Roewer, 1954: 329. Listed only. 
Oxyopes gregarius (Urquhart); Roewer, 1954: 329. Listed only.

Oxyopes gracilipes (White); Bonnet, 1958: 3228. Listed only

Oxyopes gregarius (Urquhart); Bonnet, 1958: 3228. Listed only

Oxyopes sp.; Forster, 1967: 93, Figs 87, 166

Oxyopes sp.; Forster \& Forster, 1970: 131, 4 Figs

Oxyopes gregarius (Urquhart); Forster \& Forster, 1973: 113, Figs 64, 65 \& Pl. 37

Oxyopes gregarius (Urquhart); Ferro et al., 1977: 15, 34

Oxyopes gregarius (Urquhart); Platnick, 1993: 104. Listed only

\section{Description}

MALE

Measurements (in mm)

$\begin{array}{lcccccc}\begin{array}{l}\text { Carapace } \\ \text { Abdomen }\end{array} & \begin{array}{l}\text { length } 1.9 \\ \text { length } 2.3\end{array} & \begin{array}{l}\text { width } 1.6 \\ \text { width } 0.9\end{array} & & \text { height } 1.2 & \\ \begin{array}{l}\text { Total body } \\ \text { Total length }\end{array} & \begin{array}{l}\text { length } 1.1 \\ \text { width } 0.9\end{array} & & & \\ & & & & & & \\ \text { Leg } 1 & \text { Femur } & \text { Patella } & \text { Tibia } & \text { Metatarsus } & \text { Tarsus } & \text { Total } \\ \text { Leg 2 } & 1.9 & 0.6 & 2.0 & 2.2 & 1.2 & 7.9 \\ \text { Leg 3 } & 1.9 & 0.6 & 1.7 & 2.0 & 0.9 & 7.1 \\ \text { Leg } 4 & 1.5 & 0.6 & 1.3 & 1.5 & 0.7 & 5.6 \\ \text { Palp } & 1.8 & 0.6 & 1.5 & 1.9 & 0.7 & 6.5 \\ & 0.7 & 0.3 & 0.3 & & 1.0 & 2.3\end{array}$

Size Range. Body length 4.0 -5.0. Cephalothorax length $1.8-2.3 \quad(\mathrm{n}=20)$

Colour. The cephalothorax is yellow-orange with three wide longitudinal brown to black stripes (Fig. 3). The sternum is yellow-orange with black mottling. The dorsal surface of the abdomen is cream with brown to black markings (Fig. 3). The ventral surface of the abdomen is mottled brown-black. The legs are yellow-orange with mottled black longitudinal stripes. The palpal cymbia are dark brown to brownblack.

Chelicerae. Promargin with 1 tooth, retromargin with 1 tooth.

Legs. Spines: Leg 1 femur cl.1.2.3. p.1 subdistal, patella d.3, tibia d.1.1.0. p.0.1.0. r.0.1.0. v.2.2.0, metatarsus d.2.2.2. p.1.1.1. r.1.1.1. v.0.0.1; Leg 2 femur d.1.2.3, patella d.3, tibia d.1.1.0. p.0.1.0. r.0.1.0. v.2.2.0, metatarsus d.2.2.2. p.1.1.1. r.1.1.1. v.0.0.1; Leg 3 femur d.1.3.3, patella d.3, tibia d.1.1.0. p.0.1.0. r.0.1.0. v.2.2.0, metatarsus d.2.2.2. p.1.1.1. r.1.1.1. v.0.0.1; Leg 4 femur d.1.1.3, patella d.3, tibia d.1.1.0. p.0.1.0. r.0.1.0. v.2.2.0, metatarsus d.2.2.2. p.1.1.1. r.1.1.1. v.0.0.1. The number of distal and subdistal spines on the femora vary between specimens and between legs on an individual specimen.

Palp. The male palp is shown in Figs 5 and 6.

\section{FEMALE}

Measurements (in mm)

$\begin{array}{lrll}\text { Carapace } & \text { length } 2.8 & \text { width } 2.0 & \text { height } 1.5 \\ \text { Abdomen } & \text { length } 4.8 & \text { width } 2.8 & \\ \text { Sternum } & \text { length } 1.3 & \text { width } 1.2 & \\ \text { Total length } 7.4 & & \end{array}$



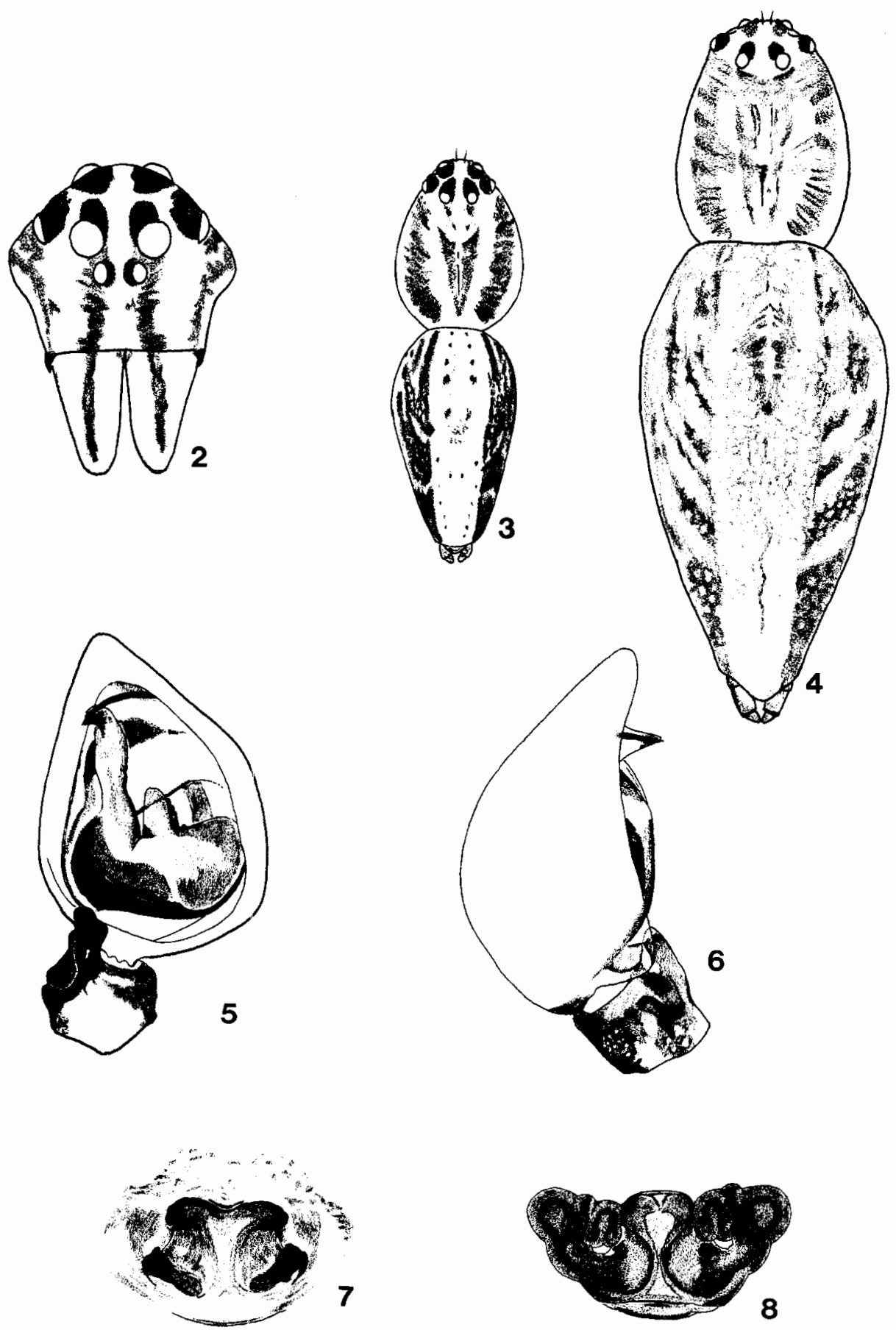

Figs 2-8: Oxyopes gracilipes. 2: Cephalothorax, front view. 3: Male body, dorsal view. 4: Female body, dorsal view. 5: Male right palp, ventral view. 6. Male right palp, retrolateral view. 7: Female genitalia, epigynum from above. 8: Internal female genitalia, from below. 


$\begin{array}{lcccccc} & \text { Femur } & \text { Patella } & \text { Tibia } & \text { Metatarsus } & \text { Tarsus } & \text { Total } \\ \text { Leg 1 } & 2.5 & 0.8 & 2.5 & 2.5 & 1.1 & 9.5 \\ \text { Leg 2 } & 2.2 & 0.7 & 2.0 & 2.1 & 0.9 & 7.9 \\ \text { Leg 3 } & 2.0 & 0.8 & 1.7 & 2.0 & 0.8 & 7.3 \\ \text { Leg } 4 & 2.4 & 0.8 & 1.9 & 2.5 & 0.9 & 8.5 \\ \text { Palp } & 0.5 & 0.4 & 0.6 & & 0.5 & 2.0\end{array}$

Size Range: Body length 5.3 - 8.8. Cephalothorax length 2.2-3.5 (n=20)

Colour. As for male except the dorsal surface of the abdomen varies in colour from yellow to silvery-white, and the ventral surface of the abdomen is cream with three wide brown-black longitudinal stripes extending the length of the abdomen (Fig. 4).

Chelicerae. Promargin with 1 tooth, retromargin with 1 tooth.

Legs. Spines: Leg 1 femur d.1.3.3. p.1 subdistal, patella d.3, tibia d.1.1.0. p.0.1.0. r.0.1.0. v.2.2.0, metatarsus d.2.2.2. p.1.1.1. r.1.1.1. v.0.0.1; Leg 2 femur d.1.4.4, patella d.3, tibia d.1.1.0 p.0.1.0. r.0.1.0. v.2.2.0, metatarsus d.2.2.2. p.1.1.1. r.1.1.1. v.0.0.1; Leg 3 femur d.1.2.3, patella d.3, tibia d.1.1.0. p.0.1.0. r.0.1.0. v.2.2.0, metatarsus d.2.2.2. p.1.1.1. r.1.1.1. v.0.0.1; Leg 4 femur d.1.2.3, patella d.3, tibia d.1.1.0. p.0.1.0. r.0.1.0. v.2.2.0, metatarsus d.2.2.2. p.1.1.1. r.1.1.1. v.0.0.1. The number of distal and subdistal spines on the femora vary between specimens and between legs on an individual specimen.

Genitalia. The female epigynum and internal genitalia are shown in Figs 7 and 8 .

\section{Type material}

Sphasus gracilipes White 1849:5. This species was described from an unspecified number of unsexed specimens collected from "New Zealand". Type/s not located by C.J.V. after a thorough search in the British Museum, Natural History, where type specimens of other species described by White were deposited.

Sphasus gregarius Urquhart 1884:51. New Synonymy. This species was described from a male and female collected by Urquhart in Karaka, Auckland. Types not located in Canterbury Museum where type specimens of other species described by Urquhart were deposited. Many of Urquhart's types were lost prior to his collection being deposited in the Canterbury Museum (Court \& Forster, 1988).

\section{Comments on synonymy and types}

White's (1849) description was clearly of an oxyopid, Sphasus gracilipes, although its brevity and lack of illustrations are insufficient to allow the differentiation of this species from other oxyopid species. Urquhart (1884) gave a clear description (including illustrations) of Sphasus gregarius. In both cases, types appear to be lost. Our examination of a large range of material leads us to conclude there is only one species in New Zealand and, therefore, Urquhart's and White's species must be the same. Thus, on the basis of nomenclatorial priority we consider Sphasus gregarius Urquhart, 1884 a junior synonym of Sphasus gracilipes White, 1849.

While type material for both S.gracilipes and $S$. gregarius is presumed lost it is not considered necessary to designate a neotype as only one species, clearly redescribed in this paper, is recognised for New Zealand.

\section{Material described}

Male - AK, near Clevedon, Thorps Bush, sweeping streamside vegetation, 27.xi.1982, P. Maddison (in 70\% alcohol, Museum of New Zealand). Female - AK, Auckland, Beachlands, 3.vi.1949, J.W. Campbell (in 70\% alcohol, Otago Museum). 
Neither specimen has a registration number but each is clearly labelled as being used for this redescription.

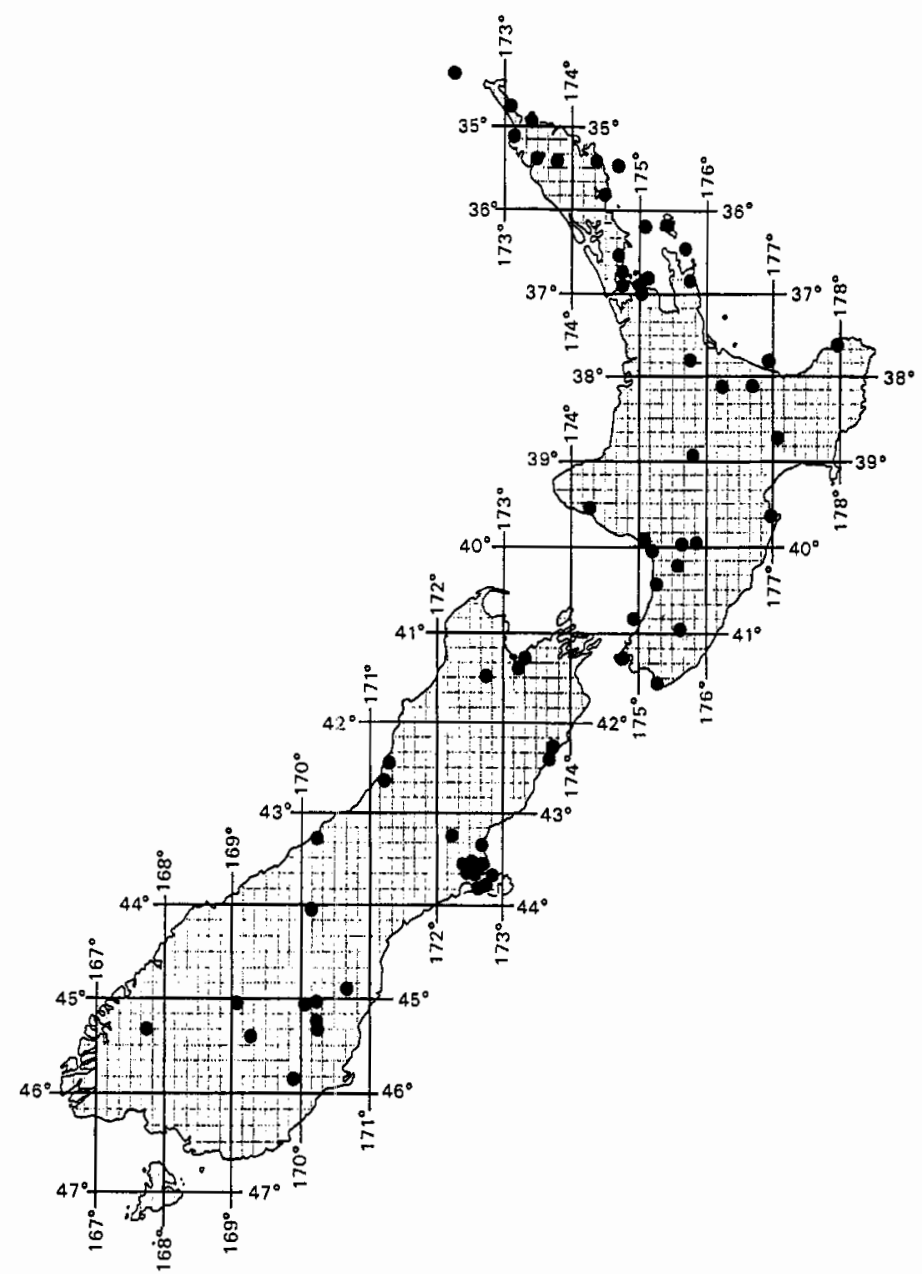

Fig. 9: Distribution of Oxyopes gracilipes in New Zealand.

\section{Distribution}

TH, ND, AK, CL, WO, BP, GB, TO, TK, HB, RI, WI, WN, WA, NN, KA, BR, NC, MC, $\mathrm{WD}, \mathrm{MK}, \mathrm{OL}, \mathrm{CO}, \mathrm{DN}$.

Oxyopes gracilipes is found throughout New Zealand north of $46^{\circ} \mathrm{S}$ and on many of the closer offshore islands, but has not been recorded on the Chatham Islands. The New Zealand geographic distribution of $O$. gracilipes is shown in Fig. 9.

\section{Remarks}

As can be seen from the description, Oxyopes gracilipes is variable in colouration. This accounts for speculation that there is more than one species present in New Zealand (Forster \& Forster, 1973). Our examination of a large number of specimens shows that colour variation is not linked to geographic distribution and also that genitalic morphology is consistent throughout. 
Oxyopes gracilipes is usually found on low shrubs, tall grass and tussock. It is a diurnal species and employs a sit-and-wait hunting strategy (Riechert \& Harp, 1987) capturing prey with a combination of running and jumping. Adults are found from October to February. Males can occasionally be found with only one palp, the missing palp probably broken off during mating. Indeed, we found one female specimen with a portion of the embolus still in the epigynum. Females can often be found with the epigynal area covered by a "plug". This is also presumed to be a consequence of mating. Note that the "plug" may distort the appearance of the epigynum quite markedly but it can be removed to allow a clear view of the external female genitalia.

The egg-sacs, covered with dirty-white silk, are usually attached to twigs and the mother remains to guard them until the spiderlings emerge (Forster, 1967; Forster \& Forster, 1973).

\section{DISCUSSION}

Oxyopes gracilipes belongs to the genus Oxyopes as defined by Brady (1964) and Dondale \& Redner (1990) and is the only species in this genus found in New Zealand. Roewer (1954) lists 14 Australian species in the genus Oxyopes, 12 of which were described by Koch (1878). There has been no revision of the Australian members of this genus since then. Oxopes gracilipes had not been recorded from Australia until it was recently collected from Tasmania (Queens Domain, Hobart, November 1997) by L.J. Boutin. A comparison of the epigyna of Oxyopes gracilipes and those of the two extant syntypes of the Australian species Oxyopes rubicundus Koch, 1878 , reveals that these two species are closely related. Unfortunately no $O$. mibicundus males from Koch's type series could be located (H. Dastych, pers. comm.), nor did we have any other verified $O$. rubicundus males. Thus, no comparison of the male palp was possible.

Berland (1932) recorded Oxyopes gracilipes (as O. gregarius Urquhart) from the Loyalty Islands, New Caledonia. However, Berland stated the identification was not certain as the only specimens he examined were subadult. As the only clear difference between $O$. gracilipes and $O$. rubicundus was genitalic we do not believe Berland's record can be regarded as valid until adult material from New Caledonia can be examined.

Oxyopes species are known to disperse by ballooning (Brady 1964) and it seems likely that $O$. gracilipes arrived in New Zealand from Australia by this method. It may also explain its widespread distribution throughout New Zealand. Despite this, it has not been found on the Chatham Islands.

The lack of speciation in Oxyopes in New Zealand contrasts with many other spider groups, particularly those with poor dispersal ability like the Mygalomorphae, where speciation has readily occurred (Forster \& Wilton, 1968; Raven, 1991; Platnick, 1993). This lack may be due to two reasons: first that $O$. gracilipes is a recent introduction from Australia and there has been insufficient time for divergence from Australian populations let alone speciation within New Zealand. Second, its dispersal abilities override the geographical barriers that lead to speciation.

\section{ACKNOWLEDGMENTS}

We thank Ricardo Palma and Adrian Paterson for comments on the manuscript. Thanks to Ray and Lyn Forster for constructive suggestions at the outset of this project and to Ricardo Palma for his invaluable advice on the finer points of taxonomic procedure. We thank John Early for editorial comments and Mike Gray and an anonymous reviewer for their careful reviews of this manuscript. We would like to thank the following individuals and institutions for the loan of material under their care: Hieronymus Dastych (Hamburg), John Early (Auckland Institute 
and Museum), Grace Hall (NZAC), Denise Nichol and John Ward (Canterbury Museum), Tony Harris and Erena Barker (Otago Museum). We thank Mark Harvey (Western Australian Museum) for supplying us with a photocopy of a valuable and hard to get reference. Thanks also to Paul Hillyard (British Museum, Natural History) for help in the search of White's type material. Special thanks to Nadine Berry, Lisa Joy Boutin, Rod Macfarlane, Andrew MacLachlan and Darryl Ubick for collecting specimens. Photo credit David Hollander.

\section{REFERENCES}

Agnew, C.W., Smith, J.W.,Jr. 1989: Ecology of spiders (Araneae) in a peanut agroecosystem. Environmental Entomology 18(1): 30-42.

Berland, L. 1932: Araignées recueillies en Nouvelle Calédonie par M. T. D. A. Cockerell. Records of the Australian Museum 18(6): 295-299.

Bonnet, P. 1958: Bibliographia Araneomum. 2 (4): 3027-4230. Douladoure, Toulouse,

Brady, A.R. 1964: The lynx spiders of North America, north of Mexico (Araneae: Oxyopidae). Bulletin of the Museum of Comparative Zoology 131: 429-518.

Brady, A.R. 1975: The lynx spider genus Oxyopes in Mexico and Central America (Araneae: Oxyopidae). Psyche 82: 189-243.

Comstock, J.H. 1912: The Spider Book. Doubleday, Page \& Company, New York, 729 p.

Court, D.J., Forster, R.R. 1988: Araneidae-Araneinae. Otago Museum Bulletin 6: 68-124.

Crosby, T.K., Dugdale, J.S., Watt, J.C. 1998: Recording specimen localities in New Zealand: an arbitrary system of areas and codes defined. New Zealand Journal of Zoology 25(2): 175183.

Cutler, B., Jennings, D.T., Moody, M.J. 1977: Biology and habitats of the lynx spider Oxyopes scalaris Hentz (Arane:ae: Oxyopidae). Entomological News 88: 87-97.

Dalmas, C. de 1917: Araignées de Nouvelle Zélande. Annales de la Société Entomologique de France 86: 317-430.

Dondale, C.D., Redner, J.H. 1990: The Wolf Spiders, Nurseryweb Spiders, and Lynx Spiders of Canada and Alaska. Araneae: Lycosidae, Pisauridae, and Oxyopidae. The Insects and Arachnids of Canada: 17. Agriculture Canada, Canada, $383 \mathrm{p}$.

Ferro, D.N., Lowe, A.D., Ordish, R.G., Somerfield, K.G., Watt, J.C. 1977: Standard Names For Common Insects of New' Zealand. The Entomological Society of New Zealand, Auckland, $42 \mathrm{p}$.

Forster, R.R. 1967: The spiders of New Zealand. Part I. Otago Museum Bulletin 1: 1-124.

Forster, R.R., Forster, L.M. 1970: Small Land Animals of New Zealand. McIndoe, Dunedin, $175 \mathrm{p}$.

Forster, R.R., Forster, L.M. 1973: New Zealand Spiders. An Introduction. Collins, Auckland, $254 \mathrm{p}$.

Forster, R.R., Wilton, C.L. 1968: The spiders of New Zealand. Part II. Otago Museum Bulletin 2: $1-180$.

Griswold, C.E. 1993: Investigations into the phylogeny of the lycosid spiders and their kin (Arachnida: Araneae: Lycosoidea). Smithsonian Contributions to Zoology 539. 1-39.

Hutton, F.W. 1904: Index Faunae Novae Zealandiae. Dulau and Co., London, 372 p.

Kayashima, I. 1961: Study on the lynx-spider Oxyopes sertatus L. Koch, for biological control of the cryptomerian leaf-fly Contarinia inouyei Mani. Publication of the Entomology Laboratory, College of Agriculture, University of Osaka 6: 167-169.

Koch, L. 1878: Die Arachniden Australiens. 1(2): 969-1044. Nürnberg.

Nakasuji, F.; Yamanaka, H.; Kiritani, K. 1973: The disturbing effect of Micryphantid spiders on the larval aggregation of the tobacco cutworm, Spodoptera litura (Lepidoptera: Noctuidae). Kontŷu 41(2): 220-227. 
Parrott, A.W. 1946: A systematic catalogue of New Zealand spiders. Records of the Canterbury Museum 5(2): 51-92.

Platnick, N.I. 1993: The araneomorph spider fauna of New Caledonia. Biodiversity Letters 1: 102-106.

Raven, R.J. 1991: A revision of the mygalomorph spider family Dipluridae in New Caledonia (Araneae). In Chazeau, J. , Tillier, S. (Eds): Zoologia Neocaledonica Mémoires Musee National Histoire Naturelle (A) 149. 87-117.

Riechert, S.E., Harp, J.L. 1987: Nutritional ecology of spiders. pp 645-672 In Slansky, F., Rodriguez, J.G. (Eds): Nutritional ecology of insects, mites, spiders and related invertebrates. New York, John Wiley \& Sons.

Roewer, C.F. 1954: Katalog der Araneae. (Vol. 2). Paul Budy, Bremen, 1751 p.

Sharma, V.K., Sarup, P. 1979: Predatory role of spiders in the integrated control of the maize stalk borer, Chilo partellus (Swinhoe). Journal of Entomological Research 3: 229-231.

Singh, B., Battu, G.S., Atwal, A.S. 1975: Studies on the spider predators of the maize borer, Chilo partellus (Swinhoe) in the Punjab. Indian Journal of Entomology 37: 72-76.

Urquhart, A.T. 1884: On the spiders of New Zealand. Transactions and Proceedings of the New Zealand Institute 17: 31-53.

Urquhart, A.T. 1885: On the spiders of New Zealand. Transactions and Proceedings of the New Zealand Institute 18: 184-205.

Urquhart, A.T. 1891: Catalogue of the described species of New Zealand Araneidae. Transactions and Proceedings of the New Zealand Institute 24: 220-230.

Urquhart, A.T. 1896: Described species of New Zealand Araneae omitted from the catalogue of 1891, "Transactions of the New Zealand Institute". Transactions and Proceedings of the New Zealand Institute 29. 284.

Whitcomb, W.H. 1962: Egg-sac construction and oviposition of the green lynx spider, Peucetia viridans (Oxyopidae). The Southwestern Naturalist 7: 198-201.

White, A. 1849: Descriptions of apparently new species of Aptera from New Zealand. Proceedings of the Zoological Society of London 1849. 3-6.

White, A. 1850: Descriptions of apparently new species of Aptera from New Zealand. Annals and Magazine of Natural History 5: 50-53.

Young, O.P., Lockley, T.C. 1985: The striped lynx spider, Oxyopes salticus (Araneae: Oxyopidae), in agroecosystems. Entomophaga 30(4): 329-346. 